\title{
A study on the mechanism of 5-aminolevulinic acid photodynamic therapy in vitro and in vivo in cervical cancer
}

\author{
GUI-FANG HE ${ }^{1}$, MEI-LU BIAN ${ }^{1}$, YA-WEI ZHAO ${ }^{1}$, QING XIANG $^{2}$, HONG-YAN LI ${ }^{2}$ and CHENG XIAO ${ }^{3}$ \\ ${ }^{1}$ Department of Gynecology and Obstetrics, China-Japan Friendship Hospital, ${ }^{2}$ Departments of \\ Biochemistry and Molecular Biology, and ${ }^{3}$ Pharmacology, Institute of Clinical Medical \\ Science, China-Japan Friendship Hospital, Beijing 100029, P.R. China
}

Received November 17, 2008; Accepted December 19, 2008

DOI: $10.3892 /$ or_00000295

\begin{abstract}
Aminolevulinic acid-mediated photodynamic therapy (ALA-PDT) is a new ablation treatment for tumors, while its function mechanism in cervical cancer has not been elucidated. In this study, we investigated the effects of ALAPDT on the cervical cancer cell line Me180, to search for optimal parameters of PDT. ALA-PDT on proliferation of Me180 was examined by MTT assay to find the optimal function parameters of ALA-PDT. Apoptosis was observed by using AnnexinV-FITC/PI double staining, Hoechst 33342 staining and May-Grünwald-Farbstoff Giemsa staining. Furthermore, we established a tumor model and 6 mice of each group underwent measurement of the tumor size on days $3,7,14$, and 21 after treatment. The mRNA expression of survivin, bcl-2, p53, bax and bad in Me180 cells were detected by real-time fluorescence reverse transcriptionpolymerase chain reaction (RT-PCR) in vitro and in vivo. Finally, we compared the effects between topical and intravenous administration. Based on the above studies, we found ALA-PDT induced apoptosis and G0-G1 phase arrest of Me180 cells. The tumor volume of the topical administration and PDT group was the smallest at 7-14 days post-PDT. H\&E staining showed remarkable subcutaneous necrosis in the PDT groups. The mRNA expression of survivin and bcl-2 in Me180 cells were suppressed post-PDT. Topical administration of PDT is recommended in treating cervical cancer so as to minimize the side-effects and inconvenience of phototoxic reaction brought by PDT. Our data may contribute to making the mechanism of PDT on cervical cancer clearer and give some useful suggestions for clinical application.
\end{abstract}

Correspondence to: Dr Mei-Lu Bian, Department of Gynecology and Obstetrics, China-Japan Friendship Hospital, Beijing 100029, P.R. China

E-mail: meilu.bian@gmail.com

Key words: aminolevulinic acid, photochemotherapy, apoptosis, cervical carcinoma, genes, mice

\section{Introduction}

Cervical cancer is the second leading cause of cancer morbidity and mortality for women around the world, especially in many developing countries. In 2005, there were, according to WHO projections, $>500,000$ new cases of cervical cancer, of which $>90 \%$ were in developing countries. It is estimated that over one million women worldwide currently have cervical cancer $(1,2)$, most of whom have no access to treatment that could cure them or prolong their life. At present the demographics of cervical cancer patients are moving towards youngsters (3), majority of this population are single or nullipara women. As a result there exists a strong demand for an effective medical treatment to cure the cancer which preserves a women's fertility function. An effective therapy (4) technique is also required for those patients who are elderly, who cannot undergo surgery or radiotherapy, and those who refused surgery, or conservative treatment.

The genesis of photodynamic therapy in reproductive system started in the mid-1970s, with the first application to cure genital herpes (5). People attempted to treat cervical lesions with PDT in the late 1980s. PDT (6), as a conservative therapy, could reserve complete organic structure for the patients, and could be repeated multiple times, if necessary, to eradicate survival lesions. Overall, the efficacy and low risk of side-effects afforded by this therapy have resulted in high patient preference in clinical trials (7).

However, ALA-PDT is still immature in treating cervical intraepithelial neoplasia and early-invasive carcinoma of the cervix (8). The fundamental scientific research is largely lagging behind, compared to the development and application of photosensitizer and laser devices. Current research could not provide a quantitative description of the process of photodynamic reaction, and interactions among the photodynamic factors. Clinicians could only treat the various patients by following the same pattern, which was built based on old experiences in the 1980s (9).

Through in vivo and in vitro experiments, our study searches for the optimal condition and accurate parameters of PDT, to analyze the mechanism of cervical cancer cell death after PDT. By comparing the effects of various modes of administration, our study identifies the optimal mode to reduce phototoxic reaction brought by PDT. The results of 
the study provide valuable references in standardizing and quantifying PDT clinical applications for millions of patients.

\section{Materials and methods}

Cell culture. The Me180 cell line was given by Dr Takeshi Yamashita from Asahikawa Medical College in Japan. The cells were routinely propagated in monolayer cultures in Dulbecco's modified Eagle's medium (Gibco-BRL, Paisley, Scotland), supplemented with 5\% heat-inactivated fetal bovine serum, $0.37 \%$ sodium bicarbonate, $30 \mathrm{mM}$ HEPES, and penicillin/streptomycin. The cells were cultured in a $5 \% \mathrm{CO}_{2}$ incubator at $37^{\circ} \mathrm{C}$. The cells were serially subcultured normally and the cells at the logarithmic growth phase were chosen for experiments.

Chemicals. ALA obtained from Aldrich and Sigma Chemical (St. Louis, MO, USA), was dissolved in PBS and PH was adjusted to 7.0 by addition of $5 \mathrm{M}$ of $\mathrm{NaOH}$. The stock solutions of $50 \mathrm{mmol} / \mathrm{l}$ were made and kept at $-20^{\circ} \mathrm{C}$ before use. All of the other chemicals used were of the highest purity commercially available.

Animals. Female BALB/c nude mice were obtained from Vitalriver Co. (Beijing, P.R. China) and maintained under specific pathogen-free conditions. The mice were 6-8 weeks old and weighed 20-25 g when the experiments started.

In vitro and in vivo treatment protocols. ALA was dissolved directly before injections. The cells under study were incubated with ALA (prepared by dissolving freeze-dried ALA in a medium) at various concentration $(10,1,0.1,0.01,0.001$, $0.0001,0.00001 \mathrm{mmol} / 1$, respectively) in serum-free medium and incubated for $4 \mathrm{~h}$. The exponentially growing cells were washed in PBS 3 times before fresh medium was added. The PDT was carried out using a He-Ne laser generator apparatus (QingHua University Laser Technology Company, P.R. China). The wavelength was set at $632.8 \mathrm{~nm}$. The cultures were then subjected to laser irradiation $\left(10,20,30 \mathrm{~J} / \mathrm{cm}^{2}\right.$, respectively), and then returned to the incubator. The cell inhibitive rate was determined by MTT assay. After the addition of photosensitizer to the cells, all procedures were carried out in minimal ambient lighting.

Animals were randomized into one of six groups (12 animals in each group): pure topical administration group (undergoing injection of ALA $60 \mathrm{mg} / \mathrm{kg}$ around the tumor), pure intravenous administration group (undergoing injection of ALA $250 \mathrm{mg} / \mathrm{kg}$ into the caudal vein), pure radiotherapy groups (undergoing radiotherapy without ALA), topical administration and PDT group (undergoing injection of ALA $60 \mathrm{mg} / \mathrm{kg}$ around tumor and radiotherapy of 630-nm He-Ne laser $3 \mathrm{~h}$ after the drug administration), intravenous administration and PDT group (undergoing injection of ALA $250 \mathrm{mg} / \mathrm{kg}$ into the caudal vein and radiotherapy of 630-nm $\mathrm{He}-\mathrm{Ne}$ laser $3 \mathrm{~h}$ after the drug administration) and control group (undergoing none of the treatment). The animals under study were treated with freeze-dried ALA dissolved in physiologic saline. The time intervals between drug administration and light irradiation were chosen as $3 \mathrm{~h}$. This was on the basis of a previous study (10).
Table I. Sequences of the primers used in PCR.

\begin{tabular}{lll}
\hline Primer & \multicolumn{1}{c}{ Sequences (5'-3') } & Length \\
\hline B-actin & F: 5'-TTGTTACAGGAAGTCCCTTGCC-3'; & $101 \mathrm{bp}$ \\
& R: 5'-ATGCTATCACCTCCCCTGTGTG-3' & \\
Survivin & F: 5'-TCCACTGCCCCACTGAGAAC-3'; & $77 \mathrm{bp}$ \\
& R: 5'-TGGCTCCCAGCCTTCCA-3' & \\
p53 & F: 5'-TCAACAAGATGTTTTGCCACTG-3'; & $101 \mathrm{bp}$ \\
& R: 5'-ATGTGCTGTGACTGCTTGTAGATG-3' & \\
Bax & F: 5'-CCTTTTCTACTTTGCCAGCAAAC-3'; & $148 \mathrm{bp}$ \\
& R: 5'-GAGGCCGTCCCAACCAC-3' & \\
bcl-2 & F: 5'-TCCGCATCAGGAAGGCTAGA-3'; & $111 \mathrm{bp}$ \\
& R: 5'-AGGACCAGGCCTCCAAGCT-3' & \\
Bad & F: 5'-GAGTGAGCAGGAAGACTCCAGC-3'; & $341 \mathrm{bp}$ \\
& R: 5'-TCCACAAACTCGTCACTCATCC-3' & \\
\hline
\end{tabular}

F, forward; R, reverse.

MTT assay. The Me180 cell lines were inoculated into an 96well at a volume of $200 \mu 1\left(5 \times 10^{4}\right.$ cells/well $)$ for stationary culture. Twenty-four hours later, different concentration of ALA was then added at a volume of $200 \mu \mathrm{l} /$ well. After a predetermined time, the ALA solution was discarded, and the culture was again washed 3 times in physiologic saline and medium added at a volume of $200 \mu \mathrm{l} / \mathrm{well}$. The cultures were then subjected to laser irradiation $\left(10,20,30 \mathrm{~J} / \mathrm{cm}^{2}\right)$. The laser radiated the single layer of cells from up to down. After radiation, DMEM was replaced with fresh DMEM medium and the cells were cultured for 1, 2, 3, 6, 12, and $24 \mathrm{~h}$ with avoidance of light. Then, for the MTT assay, $20 \mu 1$ of $5 \mathrm{X}$ MTT was added to each cell-culture well and cultured for $3 \mathrm{~h}$. Dimethylsulfoxide $(200 \mu 1)$ was added to the culture, shaken for $10 \mathrm{~min}$, and the absorbance measured with an microplate reader (Multiskan MS, Labsystem, Finland) at $492 \mathrm{~nm}$. Measurements were performed at 1, 2, 3, 6, 12, and $24 \mathrm{~h}$ after the laser irradiation to screen the optimal function time of ALA-PDT. Each group consisted of four wells; the means of their values were used as the measured values. The cell inhibitive rate was calculated according to the formula: Cell inhibitive rate $(\%)=[(\mathrm{OD}$ values of control cells - OD values of treated cells)/OD values of control cells] x $100 \%$. The time course of the changes in inhibitive rate after laser irradiation was observed.

Morphologic changes induced by PDT. After the ALA-PDT functioned for $3 \mathrm{~h}$, cytospin slides were gathered and cell climbing slides were prepared in the same manner. Then the cells were fixed with methanol. The cell nuclei were stained by May-Grünwald-Farbstoff for $4 \mathrm{~min}(2.5 \mathrm{~g}$ per $1000 \mathrm{ml})$ and then were cleansed with distilled water. Giemsa $(0.5 \mathrm{~g}$ glycerol per $33 \mathrm{ml}$ for $2 \mathrm{~h}$ at $56^{\circ} \mathrm{C}$ and then $33 \mathrm{ml}$ methanol added) was used to counterstain the cytoplasm for $15 \mathrm{~min}$. Then the cells were cleansed with tap water. When the cells dried, they were kept transparent by xylene, and neutral resin 
was used to seal the slides. The cell morphology was observed under a microscope.

After PDT treatment, the cells were incubated in the dark with Hoechst 33342 (Beyotime Biotechnology, P.R. China) for $30 \mathrm{~min}$ at $37^{\circ} \mathrm{C}$ and were then observed with a fluorescence microscope to detect morphologic changes in the nuclear chromatin of cells undergoing apoptosis compared with control.

Apoptotic analysis using dual Annexin V-FITC/propidium iodide. The Me180 cells were inoculated in the 6-well plate and were cultured for $24 \mathrm{~h}$. After the medium was replaced with the fresh, ALA was added to maintain the final concentration of $0.1,1$ and $2 \mathrm{mmol} / \mathrm{l}$. In the meantime, the blank control group was set up. At $6 \mathrm{~h}$ after ALA was added, the radiation energy of $20 \mathrm{~J} / \mathrm{cm}^{2}$ was adopted for radiation. Then the DMEM was replaced with fresh medium and the cells continued to be cultured for 3 and $24 \mathrm{~h}$ with avoidance of light. The cells were gathered and cleansed by PBS twice. Cell suspensions were centrifuged and resuspended in phosphatebuffered saline (PBS) to a concentration of $10^{6}$ cells $/ \mathrm{ml}$. For flow cytometric analysis, cells were incubated with $5 \mu 1$ of Annexin V-fluorescein isothiocyanate (BD, Pharmingen) and $10 \mu \mathrm{l}$ of propidium iodide (PI) in the dark at room temperature for $10 \mathrm{~min}$ followed by fixation with $2 \%$ formaldehyde. The stained cells were analyzed for DNA content by fluorescenceactivated cell sorting (FACS) in a FACScan (Beckman Coulter Epics XL, USA). The forward- and side-scatter gates were set to exclude any dead cells from the analysis; at least 10,000 events were collected for each sample. The observations were performed at 3 and $24 \mathrm{~h}$ after PDT.

Cell cycle analysis using propidium iodide. The culture medium was removed and saved after the ALA-PDT functioned for $24 \mathrm{~h}$, cells were trypsinized and returned to the medium they had grown in and then centrifuged. The cells were then washed twice in ice-cold phosphate-buffered saline (PBS) and stored at $-20^{\circ} \mathrm{C}$ in $80 \%$ ethanol until required. Fixed cells were resuspended in $50 \mu 1$ RANse $(0.1 \mathrm{U} / \mathrm{ml})$ and $300 \mu 1$ of the stoichiometric dye propidium iodide $(50 \mu \mathrm{g} / \mathrm{ml})$. Cells were incubated at $4^{\circ} \mathrm{C}$ overnight prior to analysis with FACScan. At least 10,000 events were collected for each sample. DNA histograms were analyzed using EXPO32 ADC software.

Real-time reverse transcription-PCR. The cells were gathered after the ALA-PDT functioned for $3 \mathrm{~h}$. RNeasy ${ }^{\circledR}$ RNA extraction kit (Qiagen) was used to extract the total RNA and the ultraviolet sepctrophotometer to measure the concentration of RNA. The RT-PCR continued according to the instructions given in the reverse transcriptase kit from MBI company.

Each cDNA sample was analyzed in triplicate (aliquot of $1 \mu 1$ each) using the ABI PRISM 7300 sequence detector (PE Applied Biosystems, Germany). Quantitative assessment of DNA amplification was detected through SYBR Green dye. The RQ-PCR reactions were carried out in a total volume of $50 \mu 1$ according to the manufacturer's manual for SYBR Green PCR Core reagent (Takara Biotechnology Inc., P.R. China). The sequence detector software 1.7 calculates the threshold cycle number $(\mathrm{Ct})$ when signals reach 10 times the
SD of the baseline. It was previously demonstrated that the calculated $\mathrm{Ct}$ values are a quantitative measurement for the mRNA levels of various genes tested. RT reaction $(2.5 \mu \mathrm{l})$, or water as control, was amplified in triplicate by real-time PCR in a final volume of $50 \mu 1$ using the SYBR Green Master mix reagent at a final concentration of $1 \mathrm{X}$ (Takara Biotechnology Inc.). The primer pairs (11-13) for detecting the expression of genes are listed in Table I.

For thermal cycling, the following conditions were applied: 2 initial incubations of $2 \mathrm{~min}$ at $50^{\circ} \mathrm{C}$ and $10 \mathrm{sec}$ at $95^{\circ} \mathrm{C}$, then 45 cycles of $5 \mathrm{sec}$ at $95^{\circ} \mathrm{C}$ and $1 \mathrm{~min}$ at $60^{\circ} \mathrm{C}$. The heating rate (ramping) between the last 2 steps was increased to $20 \mathrm{~min}$ to obtain a melting curve of the final RQ-PCR products (PE Applied Biosystems). This is necessary because SYBR Green flurescence may also be derived from side products such as primer-dimers. The $\Delta \mathrm{Ct}$ values was calculated according to the following formula: $\Delta \mathrm{Ct}_{\text {target gene of PDT group }}=\mathrm{Ct}_{\text {target gene of PDT group }}$ - $\mathrm{Ct}_{\mathrm{B} \text {-actin of the same sample }} ; \Delta \mathrm{Ct}_{\text {target gene of control group }}=\mathrm{Ct}_{\text {target gene of control }}$

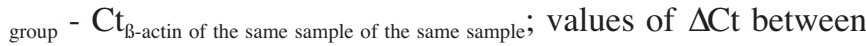
different groups were compared.

Inhibition of tumor growth. The responses of treatments were evaluated by measuring survival rates and tumor size. The following protocol of experiments was used. A $0.1 \mathrm{ml}$ of PBS suspension $\left(5 \times 10^{6}\right.$ cells $\left./ \mathrm{ml}\right)$ of Me180 cells was injected subcutaneously with a syringe into the flank of mice. At this site the tumor was easily accessible to treatment and to assessment of response. After the cancer cells were allowed to grow to a certain level, ALA was injected of each mouse of the PDT group. The photodynamic treatment was carried out $24 \mathrm{~h}$ after the drug administration using 630-nm radiation of a He-Ne laser. The tumor volume was calculated using the following formula: $V=\pi / 6\left(D_{1} \times D_{2} \times D_{3}\right)$, where $D_{1}, D_{2}$ and $D_{3}$ were three orthogonal diameters of the tumors that were evaluated once every 2 days for 3 weeks using calipers, and tumor size calculated based on average dimensions. No spontaneous necrosis was observed in the tumors on the day of treatment. The tumors were resected on the days indicated and stored at $-70^{\circ} \mathrm{C}$.

Histopathologic examination. After measuring the gross tumor size, the specimens were embedded in paraffin, cut into $5-\mu \mathrm{m}$ slices, and mounted on slides. The sample was stained with hematoxylin-eosin and examined under a light microscope.

Statistical analysis. The data were calculated and analyzed via the Excel and SPSS 10.0 package. Statistical analysis was done using the paired Student's t-test and ANOVA. Values between different groups were compared. $\mathrm{P}<0.05$ was considered significant.

\section{Results}

Cell growth-suppression activity of PDT. ALA-PDT does have the effects of growth inhibition on all cervical cancer lines in vitro, the phototoxic $\mathrm{IC}_{50}$ concentration in Me180 is $7.28 \times 10^{-4} \mathrm{mM}$. Fig. 1 shows the concentrations of ALA that give rise to $50 \%\left(\mathrm{IC}_{50}\right), 75 \%\left(\mathrm{IC}_{75}\right)$, and $90 \%\left(\mathrm{IC}_{90}\right)$ growth inhibition of Me180 cells. From $1 \times 10^{-4}$ to $1 \times 10^{-1} \mathrm{mmol} / \mathrm{l}$, the proliferation inhibition rate increased regarding the increase 


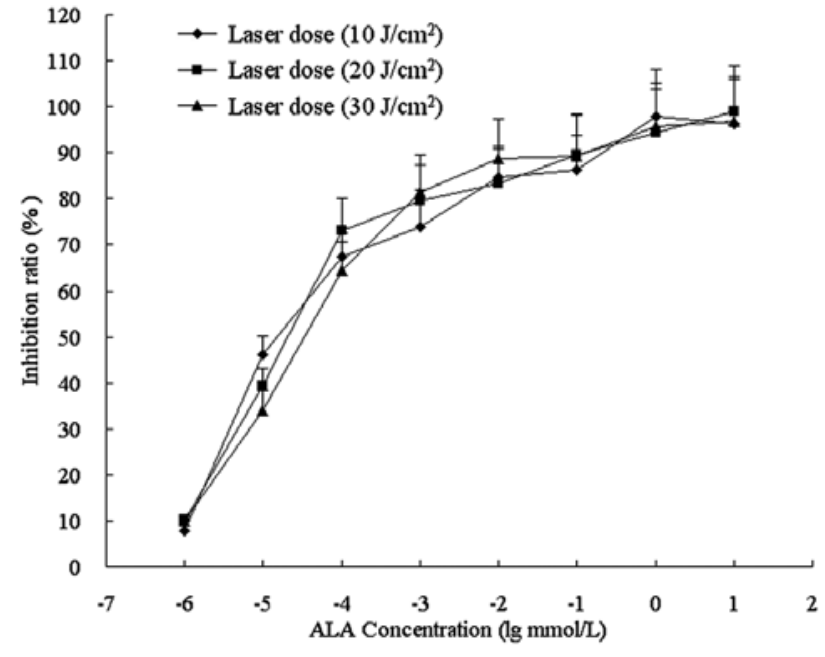

Figure 1. Cell growth-suppression effect of PDT. Cervical cancer cell Me180 was grown in different concentration of ALA $\left(10^{-6}-10 \mathrm{mmol} / \mathrm{l}\right)$ and different laser irradiation $\left(10,20,30 \mathrm{~J} / \mathrm{cm}^{2}\right)$. Also the inhibition of cells was determined by the MTT assay.

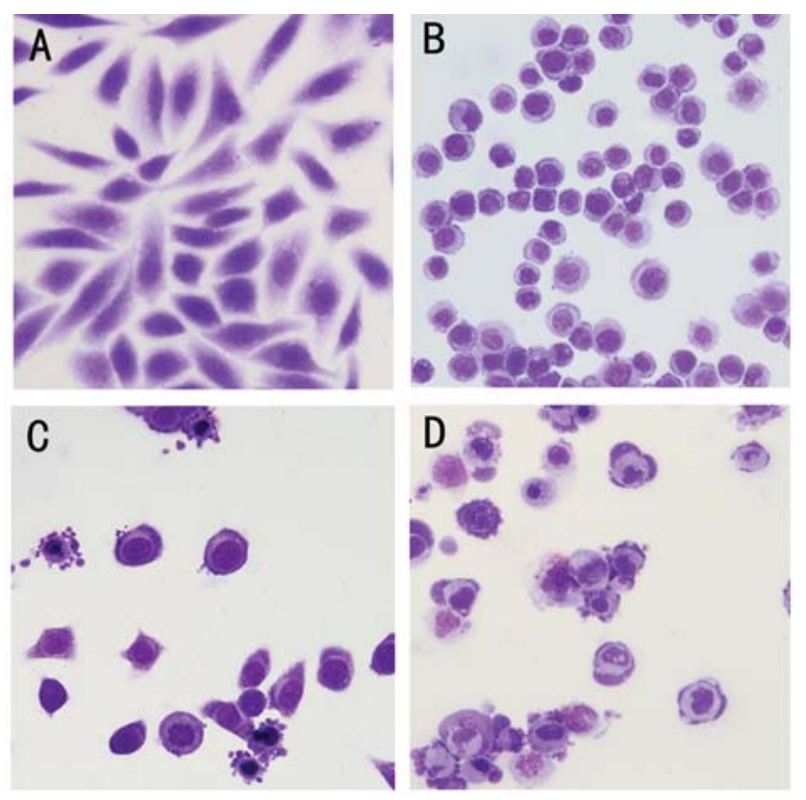

Figure 2. Morphologic changes of ALA-PDT on apoptosis of Me180 cells (May-Grünwald-Farbstoff Giemsa staining, x400). (A) Control (cell climbing slide): normal Me180 cells; (B) Control (cell cytospin slide): normal Me180 cells; (C) 1 mmol/l ALA-PDT (cell climbing slide): nuclear projection and polytypic apoptotic bodies can be seen in Me180 cells; (D) $1 \mathrm{mmol} / \mathrm{l}$ ALA-PDT (cell cytospin slide): cell apoptosis and cell necrosis can be seen.

of the drug concentration $(\mathrm{P}<0.01)$. From 0.1 to $10 \mathrm{mmo} 1 / 1$, the cell proliferation inhibition rate did not increase obviously. There is no obvious phototoxic reaction at $<10 \mathrm{mM}$ and $30 \mathrm{~J} / \mathrm{cm}^{2}$.

The $\mathrm{IC}_{50}$ was $(9.99 \pm 0.24) \times 10^{-3} \mathrm{mmol} / 11 \mathrm{~h}$ post-PDT. It increased gradually at 2 and $3 \mathrm{~h}$, and reaches its peaks at $4 \mathrm{~h}$ post-PDT that $\mathrm{IC}_{50}$ was $(5.05 \pm 0.22) \times 10^{-4} \mathrm{mmol} / \mathrm{l}$. There is significantly difference comparing to 1,2 and $3 \mathrm{~h}$. The $\mathrm{IC}_{50}$ decreased at $6,12,24 \mathrm{~h}$ post-PDT. The $\mathrm{IC}_{50}$ at $24 \mathrm{~h}$ was $(1.45 \pm 0.24) \times 10^{-3} \mathrm{mmol} / \mathrm{l}$. The optimal results come at $4 \mathrm{~h}$ after ALA-PDT.
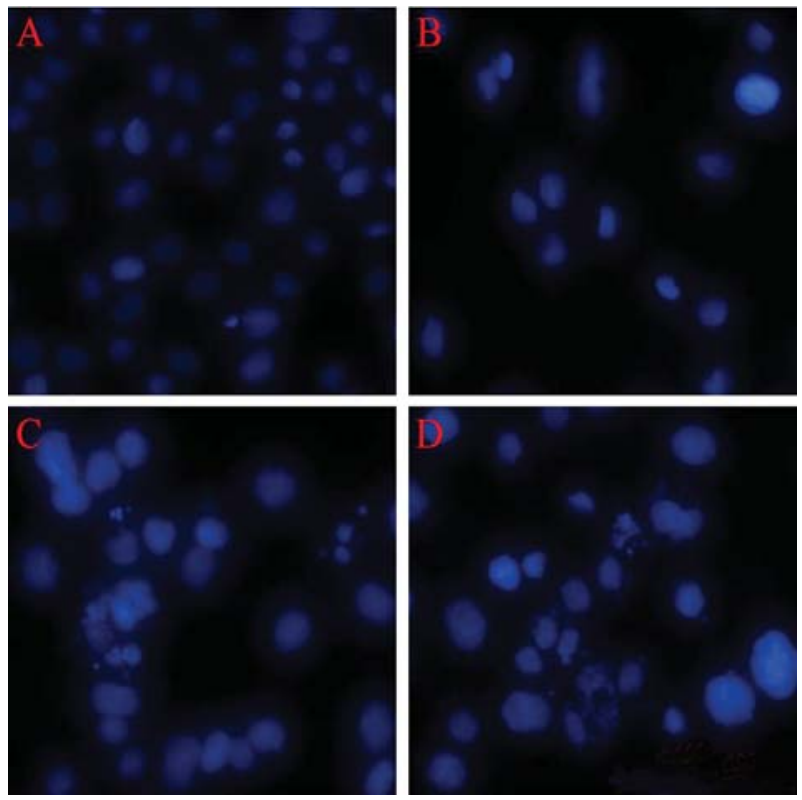

Figure 3. Effects of ALA-PDT on apoptosis of Me180 cells (Hoechst 33342, x200). (A) Only a few apoptotic cells can be seen in control group; (B) Certain swollen cells can be seen after treatment of $0.1 \mathrm{mmol} / \mathrm{l}$ ALA. (C) Apoptotic cells and apoptotic bodies can be seen after treatment of $1 \mathrm{mmol} / \mathrm{l}$ ALA. (D) More apoptotic cells and apoptotic bodies, swollen cells and cell death can be seen after treatment of $2 \mathrm{mmol} / \mathrm{l}$ ALA.

Table II. Effects of ALA-PDT on cell cycle of Me180 cells at $24 \mathrm{~h}$.

\begin{tabular}{llll}
\hline & \multicolumn{3}{c}{ Cell proportion (\%) } \\
\cline { 2 - 4 } Group & G0-G1 & $\mathrm{S}$ & $\mathrm{G} 2 / \mathrm{M}$ \\
\hline Control & $42.64 \pm 3.23$ & $29.25 \pm 4.34$ & $28.97 \pm 4.78$ \\
ALA-PDT $(0.1 \mathrm{mmol} / \mathrm{l})$ & $45.28 \pm 5.54$ & $27.31 \pm 5.43$ & $28.26 \pm 5.34$ \\
ALA-PDT $(1 \mathrm{mmol} / \mathrm{l})$ & $61.06 \pm 6.97^{\mathrm{b}}$ & $20.12 \pm 3.12^{\mathrm{a}}$ & $18.83 \pm 4.39^{\mathrm{b}}$ \\
ALA-PDT $(2 \mathrm{mmol} / \mathrm{l})$ & $69.58 \pm 5.12^{\mathrm{c}}$ & $14.21 \pm 2.14^{\mathrm{c}}$ & $16.11 \pm 3.47^{\mathrm{c}}$ \\
\hline
\end{tabular}

All values are presented as mean $\pm \mathrm{SD}$ of 3 experiments. ${ }^{\mathrm{a}} \mathrm{P}<0.05$, ${ }^{\mathrm{b}} \mathrm{P}<0.01,{ }^{\mathrm{c}} \mathrm{P}<0.001$, vs. control.

Morphologic changes after PDT. We detected abundant amounts of apoptotic cells and some necrotic cells both by May-Grünwald-Farbstoff Giemsa (Fig. 2) and Hoechst 33342 staining (Fig. 3). Cell apoptosis was observed by monitoring cellular shape, May-Grunwald Giemsa staining, Hoechst 33342 and DNA content analysis using flow cytometry.

DNA cell cycle analysis. No significant cell cycle effects were evident at $4 \mathrm{~h}$ post-PDT, and the distribution of cell cycle significantly changed at $24 \mathrm{~h}$ post-PDT; an appreciable accumulation of cells residing in G0/G1 phase was induced at $1-2 \mathrm{mM}$, the reverse was seen in the $\mathrm{S}$ and $\mathrm{G} 2 / \mathrm{M}$ phase (Table II).

Cell death analysis. Me180 cell death is significantly induced post ALA-PDT, in which the pattern of early apoptosis shows 


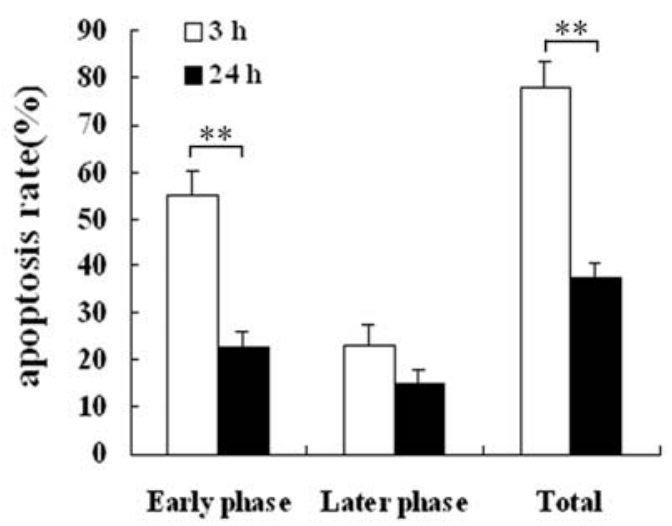

Figure 4. The degree of apoptosis was assessed $3 \mathrm{~h}$ and $24 \mathrm{~h}$ post-PDT as determined by flow cytometric analysis of the Annexin-FITC/PI double staining method; ${ }^{* *} \mathrm{P}<0.01$.

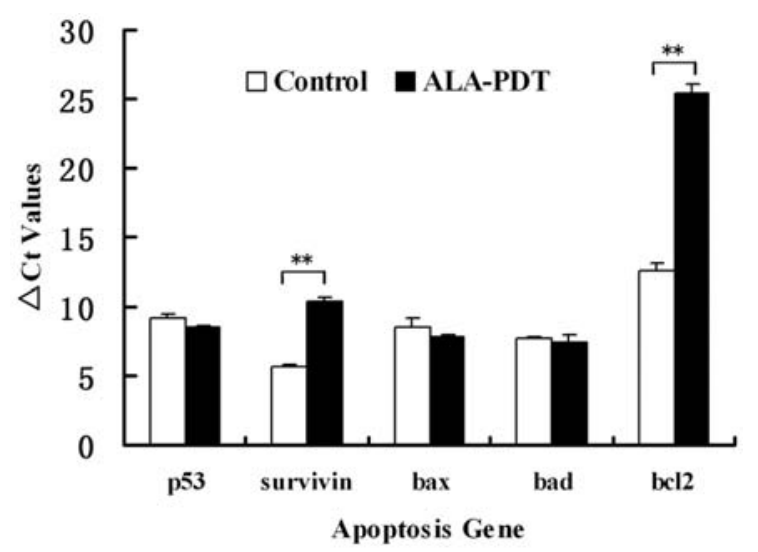

Figure 5. Effects of ALA-PDT on the mRNA expression of certain apoptosis genes in Me180 cells (real-time RT-PCR); ${ }^{* *} \mathrm{P}<0.01$.

at $3 \mathrm{~h}$ post-PDT, and the total rate of apoptosis declines in $24 \mathrm{~h}$ post-PDT (Fig. 4), which could be considered as a different phase issue. The total rate of apoptosis for 1 and $2 \mathrm{mM}$ are 52.45 and $77.92 \%$ respectively, 3 h post-PDT.

Real-time quantitative RT-PCR analysis in vitro. Results representative of real-time quantitative PCR are shown in Fig. 5 for bcl-2, survivin, p53, bax and bad. The $\Delta C_{t}$ value of bcl-2 and survivin post-PDT is higher than control cells, which is reflective of a lower mRNA expression for bcl-2 and survivin $(\mathrm{P}<0.001)$. We observed that the $\Delta \mathrm{C}_{\mathrm{t}}$ value of $\mathrm{p} 53$, bax and bad had only increased slightly $(\mathrm{P}>0.05)$.

Antitumor activity of PDT. The results of tumor inhibition experiment in vivo demonstrate that, the tumor volume was significantly reduced post-PDT by topical and caudal vein administration $(\mathrm{P}<0.001)$, in which the most significant effect was seen at 7-14 days post-PDT (Fig. 6).

Hematoxylin and eosin staining. The results of hematoxylin and eosin staining demonstrate that, there is no appreciable change in the control group, however, severe local region necrosis showed up in PDT group with severe morphological change of the tumor cells (Fig. 7).

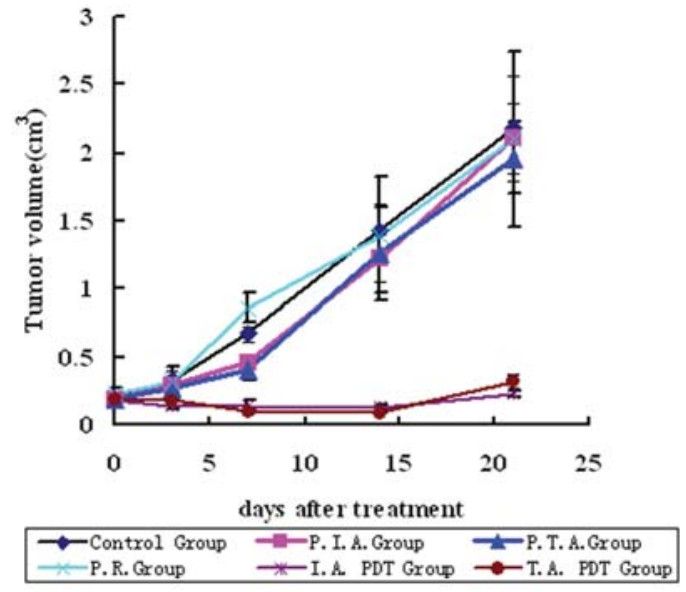

Figure 6. Tumor growth curves of mice treated by several protocols. P.I.A. group: pure intravenous administration group; P.T.A. group: pure topical administration group; P.R. group: pure radiotherapy group; I.A. PDT group: intravenous administration + PDT group; T.A. PDT group: topical administration + PDT group.

Real-time quantitative RT-PCR analysis in vivo. Results representative of real-time quantitative PCR are shown in Fig. 8 for bcl-2, survivin, p53, bax and bad. The $\Delta \mathrm{C}_{\mathrm{t}}$ value of bcl-2 and survivin post-PDT is higher than control group, which is reflective of a lower mRNA expression for bcl-2 and survivin $(\mathrm{P}<0.001)$. We observed that the $\Delta \mathrm{C}_{\mathrm{t}}$ value of p53, bax and bad had only increased slightly $(\mathrm{P}>0.05)$.

\section{Discussion}

Different optimal PDT parameters have been reported (1416). That could be caused by various types of cells, photosensitizers, and wavelength of laser chosen by different research entities. We found that ALA-PDT can inhibit the growth of cervical cancer cells in vitro. PDT is effective (1719). After treatment with concentration $<10^{-1} \mathrm{mM}$, the cell survival rate decreased sharply. It shows a slower decrease when the concentration is $>10^{-1} \mathrm{mM}$, thereafter reaching a plateau. In ALA-PDT, 5-ALA itself does not serve as photosensitizer but as the biological precursor in the heme biosynthetic pathway $(12,20)$, which produces protoporphyrin IX (PpIX), a potent photosensitizer, in response to 5-ALA-induced endogenous photosensitization. Cellular PpIX production increased, as suggested by our findings, after treatment of the cells with 5-ALA at relatively lower concentrations, and this increment exhibited saturation with higher concentrations of 5-ALA. As PpIX is the product in the heme biosynthetic pathway whose biosynthetic capacity is limited (21), the saturation of cellular PpIX production at higher 5-ALA concentration is not surprising. This finding may potentially help in deciding the optimal dose of 5-ALA in future clinical PDT.

The Annexin-V/PI technique has previously been employed in PDT studies and many types of mammalian cells undergo apoptosis after exposure to PDT $(22,23)$. The cell death increased significantly after $1 \mathrm{~h}$ of PDT, and reached its peaks at $4 \mathrm{~h}$ and decreased gradually since $6 \mathrm{~h}$. Also the cell re-growth tendency appeared after $24 \mathrm{~h}$ post-PDT. We speculate that the cell proliferation counteracted part of lethal 

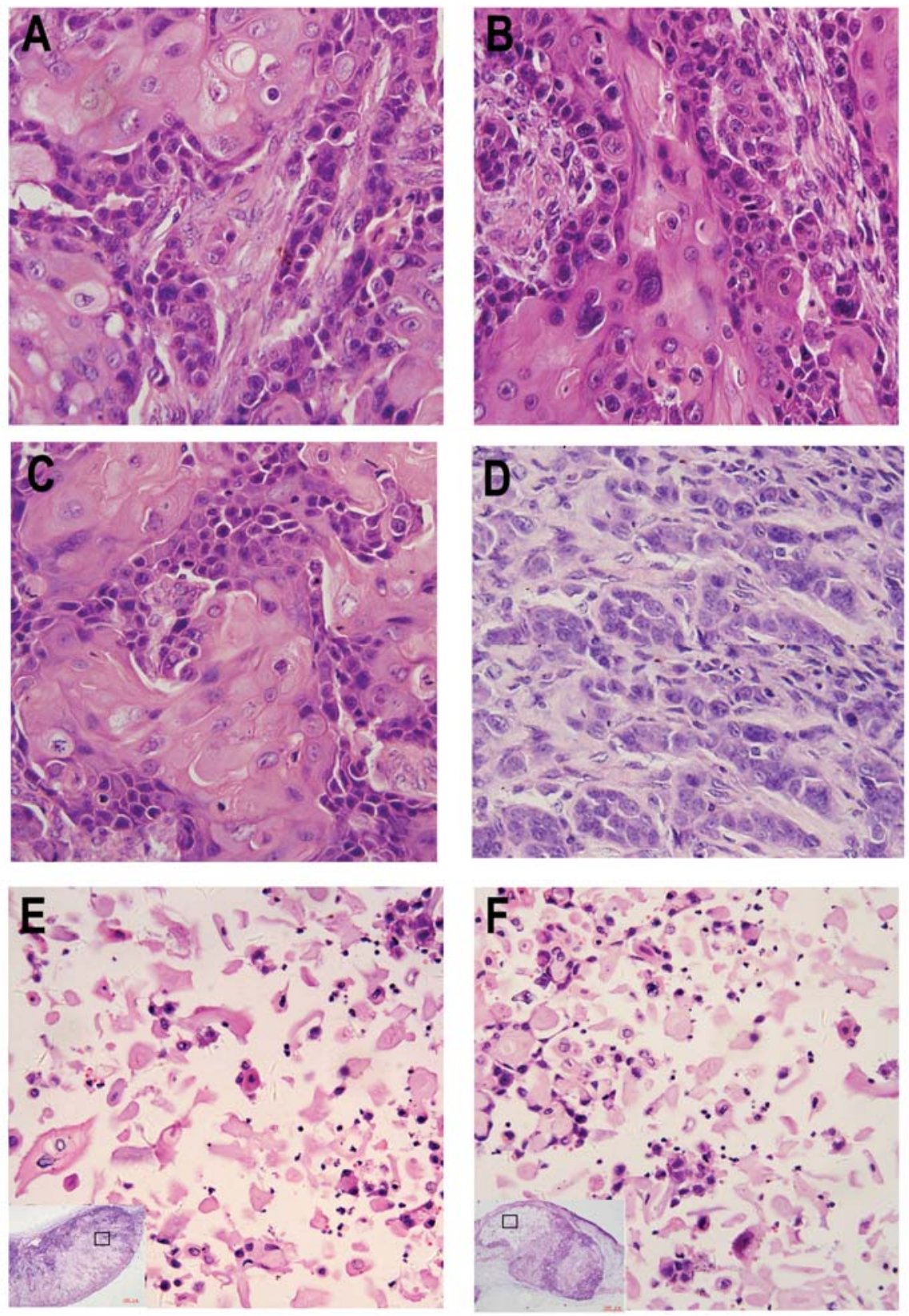

Figure 7. (A) Control group; (B) pure intravenous administration group; (C) pure topical administration group; (D) pure radiotherapy group; (E) intravenous administration + PDT group; (F) topical administration + PDT group.

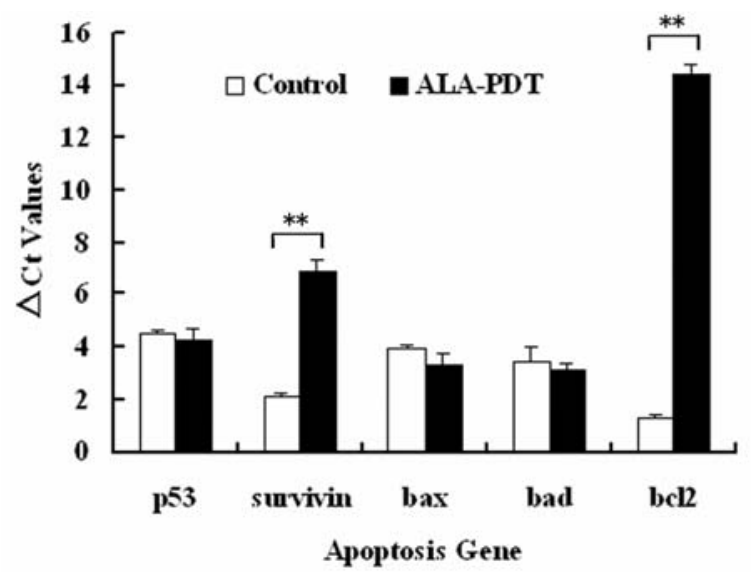

Figure 8. Effects of ALA-PDT on the mRNA expression of certain apoptotic genes in tumor tissue (real-time RT-PCR) ${ }^{* *} \mathrm{P}<0.01$ effects. The perturbation of cell cycle appeared at $24 \mathrm{~h}$ post-PDT. An appreciable accumulation of cells residing in G0/G1 phase was induced at $1-2 \mathrm{mM}$, the reverse results were seen in the S and G2/M phase, as described (24). Almost all cells were destroyed when ALA $2 \mathrm{mM}$, effective light dose $10 \mathrm{~J} / \mathrm{cm}^{2}$ and $4 \mathrm{~h}$ post-PDT, which are the most optimal parameters.

The main purpose of in vivo study is to find a better mode of this drug so that phototoxicity of normal tissues could be avoided, while the effects retained. Tumor inhibition experiments in vivo demonstrated that there is no significant difference in therapy effects between the inhibition rate of intravenous (89.79\%) and topical $(85.44 \%)$ application. However, comparing the intravenous administration and the topical application, the topical application brings lower systemic uptake. Therefore, the topical administration is better 
mode (25) to reduce the phototoxic reaction in the PDT for cervical cancer.

The tumor volume was significantly reduced post-PDT by topical and caudal vein administration comparing to control group $(\mathrm{P}<0.001)$. In which the most significant effect of tumor size reduced the most, observed at topical treatment 7 14 days post-PDT. Our data are in agreement with the result of Ahn et al (26). It is helpful in deciding the optimal timing of the second PDT treatment. After 14 days, the size of tumor starts to increase again, which proves that the inhibitive time of single time PDT is un-abiding. The cause could be that the penetration depth of laser is limited, and the basal part of tumor keeps growing while the superficial layer necrosed. To improve the clinical effects, we suggest providing multiple periods of interrupted treatment. Also histologic analysis showed that PDT-treated tumors demonstrated necrosis and inflammation that was not seen in the control.

Previous studies have demonstrated complexity of cell death induced by PDT between various cell types in intracellular accumulation and phototoxicity of photosensitizer (27-29). It is reasonable to suppose that different photosensitizers, laser dose acting on different type of target cells would lead to different results. Those mechanisms are unclear (30-32). Various studies from in vitro culture systems and in vivo animal models have been proposed to explain the mechanism of both necrosis and apoptosis of the target cells by PDT $(33,34)$. In this study, we evaluated the mRNA changes of related apoptosis genes. The in vivo and in vitro mRNA expression of survivin and bcl-2 was down-regulated in the experimental groups versus the control group $(\mathrm{P}<0.01)$, the mRNA expression of $\mathrm{p} 53$, bax, and bad was up-regulated in the experimental groups $(\mathrm{P}>0.05)$. It suggests that the cell death and necrosis of tumor tissue after PDT has high correlation with survivin and bcl-2. Our results might help in formulating new therapeutic approaches in photodynamic therapy. Future studies could be designed to document the precise pathway to apoptosis in cervical cancer, enhancing the induction of apoptosis.

In conclusion, the analyzing experiments in vivo and in vitro, indicate that ALA-PDT is an effective therapy for cervical cancer. We found that ALA-PDT exerts its anti-tumor activity primarily by inducing apoptosis. As such, we infer that early induction of apoptosis of Me180 is one of the important mechanisms in vitro and in vivo. The observations may be useful in understanding the apoptosis pathway by PDT. Topical administration of PDT is recommended in treating cervical cancer so as to minimize the side-effects and inconvenience of phototoxic reaction brought on by PDT.

\section{References}

1. Downs LS, Smith JS, Scarinci I, Flowers L and Parham G: The disparity of cervical cancer in diverse populations. Gynecol Oncol 109: 22-30, 2008

2. Greer BE, Koh WJ, Abu-Rustum N, Bookman MA, Bristow RE, Campos S, Cho KR, Copeland L, Eifel P, Huh WK, Jaggernauth W, Kapp DS, Kavanagh J, Lipscomb GH, Lurain JR III, Morgan M, Morgan RJ Jr, Powell CB, Remmenga SW, Reynolds RK, Secord AA, Small W Jr and Teng N: Cervical cancer. J Natl Compr Cancer Netw 6: 14-36, 2008.

3. Wells SF: Cervical cancer: an overview with suggested practice and policy goals. Medsurg Nurs 17: 43-50, 2008.
4. Bodner K, Bodner-Adler B, Wierrani F, Kubin A, Szölts-Szölts J, Spängler B and Grünberger W: Cold-knife conization versus photodynamic therapy with topical 5 -aminolevulinic acid (5-ALA) in cervical intraepithelial neoplasia (CIN) II with associated human papillomavirus infection: a comparison of preliminary results. Anticancer Res 23: 1785-1788, 2003.

5. Juarranz A, Jaén P, Sanz-Rodríguez F, Cuevas J and González S: Photodynamic therapy of cancer. Basic principles and applications. Clin Transl Oncol 10: 148-154, 2008.

6. Palumbo G: Photodynamic therapy and cancer: a brief sightseeing tour. Expert Opin Drug Deliv 4: 131-148, 2007.

7. Lehmann P: Methyl aminolaevulinate-photodynamic therapy: a review of clinical trials in the treatment of actinic keratoses and nonmelanoma skin cancer. Br J Dermatol 156: 793-801, 2007.

8. James RM, Cruickshank ME and Siddiqui N: Guideline Development Group. Management of cervical cancer: summary of SIGN guidelines. BMJ 336: 41-43, 2008.

9. Harrod-Kim P: Tumor ablation with photodynamic therapy: introduction to mechanism and clinical applications. J Vasc Interv Radiol 17: 1441-1448, 2006.

10. Peng Q, Warloe T, Moan J, Godal A, Apricena F, Giercksky K-E and Nesland JM: Antitumor effect of 5-aminolevulinic acidmediated photodynamic therapy can be enhanced by the use of a low dose of photofrin in human tumor xenografts. Cancer Res 61: 5824-5832, 2001.

11. Peng XH, Cao ZH, Xia JT, Carlson GW, Lewis MM, Wood WC and Yang L: Real-time detection of gene expression in cancer cells using molecular beacon imaging: new strategies for cancer research. Cancer Res 1: 1909-1917, 2005.

12. Korz C, Pscherer A, Benner A, Mertens D, Schaffner C, Leupolt E, Döhner H, Stilgenbauer S and Lichter P: Evidence for distinct pathomechanisms in B-cell chronic lymphocytic leukemia and mantle cell lymphoma by quantitative analysis of cell and apoptosis-associated genes. Blood 99: 4454-4461, 2002.

13. Kennedy JC and Pottier RH: Endogenous protoporphyrin IX: a clinically useful photosensitizer for photodynamic therapy. J Photochem Photobiol B 24: 275-292, 2002.

14. Perotti C, Fukuda H, DiVenosa G, MacRobert AJ, Batlle A and Casas A: Porphyrin synthesis from ALA derivatives for photodynamic therapy. In vitro and in vivo studies. Br J Cancer 90: 1660-1665, 2004.

15. Alvarez MG, Lacelli MS, Rivarola V, Batlle A and Fukuda H: 5-aminolevulinic acid-mediated photodynamic therapy on Hep-2 and MCF-7c3 cells. J Environ Pathol Toxicol Oncol 26: 75-82, 2007.

16. McCarron PA, Donnelly RF and Woolfson AD: Autoradiographic and scintillation analysis of 5-aminolevulinic acid permeation through epithelialised tissue: implications for topical photodynamic therapy of superficial gynaecological neoplasias. Pharm Res 25: 812-826, 2008.

17. Pazos MC and Nader HB: Effect of photodynamic therapy on the extracellular matrix and associated components. Braz J Med Biol Res 40: 1025-1035, 2007.

18. Keeley SB, Pennathur A, Gooding W, Landreneau RJ, Christie NA and Luketich J: Photodynamic therapy with curative intent for Barrett's esophagus with high grade dysplasia and superficial esophageal cancer. Ann Surg Oncol 14: 2406-2410, 2007.

19. Ramaiah D, Eckert I, Arun KT, Weidenfeller L and Epe B: Squaraine dyes for photodynamic therapy: mechanism of cytotoxicity and DNA damage induced by halogenated squaraine dyes plus light (>600 nm). Photochem Photobiol 79: 99-104, 2004.

20. Fukuda H, Casas A and Batlle A: Use of ALA and ALA derivatives for optimizing ALA-based photodynamic therapy: a review of our experience. J Environ Pathol Toxicol Oncol 25: 127-143, 2006.

21. de Bruijn HS, Kruijt B, van der Ploeg-van den Heuvel, Sterenborg HJ and Robinson DJ: Increase in protoporphyrin IX after 5-aminolevulinic acid based photodynamic therapy is due to local re-synthesis. Photochem Photobiol Sci 6: 857-864, 2007.

22. Park S, Hong SP, Oh TY, Bang S, Chung JB and Song SY: Paclitaxel augments cytotoxic effect of photodynamic therapy using verteporfin in gastric and bile duct cancer cells. Photochem Photobiol Sci 7: 769-774, 2008.

23. Mitsunaga M, Tsubota A, Nariai K, Namiki Y, Sumi M, Yoshikawa T and Fujise K: Early apoptosis and cell death induced by ATX-S10Na (II)-mediated photodynamic therapy are Bax- and p53-dependent in human colon cancer cells. World J Gastroenterol 13: 692-698, 2007. 
24. Haywood-Small SL, Vernon DI, Griffiths J, Schofield J and Brown SB: Phthalocyanine-mediated photodynamic therapy induces cell death and a G0/G1 cell cycle arrest in cervical cancer cells. J Biochem Biophys Res Commun 339: 569-576, 2006.

25. Ibbotson SH: Opical 5-aminolaevulinic acid photodynamic therapy for the treatment of skin conditions other than nonmelanoma skin cancer. Br J Dermatol 146: 178-188, 2002.

26. Ahn WS, Bae SM, Huh SW, Lee JM, Namkoong SE, Han SJ, Kim CK, Kim JK and Kim YW: Necrosis-like death with plasma membrane damage against cervical cancer cells by photodynamic therapy. Int J Gynecol Cancer 14: 475-482, 2004.

27. Buytaert E, Dewaele M and Agostinis P: Molecular effectors of multiple cell death pathways initiated by photodynamic therapy. Biochim Biophys Acta 1776: 86-107, 2007.

28. Prignano F, Bianchi B, Domenici L, Rossi R, Romagnoli P, Pimpinelli N, Cappugi P and Giannotti B: Early apoptosis plays an important role in the healing mechanism of cutaneous basa cell carcinomas after photodynamic therapy. Br J Dermatol 149: 205-206, 2003

29. Xue LY, Chiu SM, Azizuddin K, Joseph S and Oleinick NL: The death of human cancer cells following photodynamic therapy: apoptosis competence is necessary for $\mathrm{Bcl}-2$ protection but not for induction of autophagy. Photochem Photobiol 83: 1016-1023, 2007 (In Russian).
30. Iagudaev DM, Sorokatyi AE, Geinits AV and Trukhmanov RS: Current views on the mechanism of photodynamic therapy. Photosensitizers and their bioavailability. Urologiia 5: 94-98, 2006.

31. Sharwani A, Jerjes W, Hopper C, Lewis MP, El-Maaytah M, Khalil HS, Macrobert AJ, Upile T and Salih V: Photodynamic therapy down-regulates the invasion promoting factors in human oral cancer. Arch Oral Biol 51: 1104-1111, 2006.

32. Karmakar S, Banik NL, Patel SJ and Ray SK: 5-Aminolevulinic acid-based photodynamic therapy suppressed survival factors and activated proteases for apoptosis in human glioblastoma U87MG cells. Neurosci Lett 415: 242-247, 2007.

33. Adams JM and Cory S: Apoptosomes: engines for caspase activation. Curr Opin Cell Biol 14: 715-720, 2002.

34. Ichinose S, Usuda J, Hirata T, Inoue T, Ohtani K, Maehara S, Kubota M, Imai K, Tsunoda Y, Kuroiwa Y, Yamada K, Tsutsui H, Furukawa K, Okunaka T, Oleinick NL and Kato H: Lysosomal cathepsin initiates apoptosis, which is regulated by photodamage to Bcl-2 at mitochondria in photodynamic therapy using a novel photosensitizer, ATX-s10 (Na). Int J Oncol 29: 349-355, 2006. 